\title{
CORRESPONDENCE.
}

\section{PERTHSHIRE TECTONICS.}

Sir,-A paper entitled "Perthshire Tectonics: Schichallion to Glenlyon " has recently been published by Drs. Bailey and MoCallien." As my previous work in the area is very frequently referred to, ${ }^{2}$ and alterations in my interpretation have been made, perhaps you will allow me space in which to reply to them.

Credit has been given to me for noting the uniformity of the pitch of the small folds, throughout the district. The authors, however, imply that, after making this observation, I have failed to draw the obvious deductions. On the evidence of the pitch they regard the Beinn a' Chuallaich fold as being a "synform". In this I am now inclined to agree with them. In the same way the Bailliemore structure may be an "antiform". Partly on this evidence they regard all the country between the synform and the eastern Dalradian boundary as being inverted. If, however, the reader of their paper will consult Fig. 3 (p. 83), he will notice the following. In the southwest corner of the area of the text-figure, pitch carries (1) Grey Limestone under Banded Group, and (2) Banded Group under White Limestone and Boulder Bed. This is well within the "inverted" area, and yet, on the authors' own principle, the beds must be here uninverted.

The structure must therefore be more complicated than Drs. Bailey and McCallien have imagined. The authors proceed to argue from the inversion that there is a marked recumbent fold in this district. Some overfolding exists, but not, according to visible indications, of a type that can reasonably be called recumbent. Its extent has also, in at least one respect, been exaggerated. As it affects the Moine-Dalradian boundary, surface evidence shows that there is overfolding of about $1 \frac{1}{4}$ mile. The authors' diagram (Fig. 15) shows this as having increased southwards, without apparent reason, to $3 \frac{1}{2}$ miles.

The following sentence appears in the summary of conclusions: "Throughout, the big movements have been towards the southeast, with local twists and adjustments." In the area of what Dr. Bailey has termed the "Loch Tay Inversion", this statement may be justified. Farther north, however, the structure becomes more complicated. The study of lineation, in its bearing on Highland problems, is at present only beginning. Its effects may well be

1 Bailey, E. B., and W. J. McCallien, Trans. Roy. Soc. Edin., 59, pt. 1, 1937, 79.

2 Anderson, E. M., "Geology of the Schists of the Schichallion District (Perthshire)," Quart. Journ. Geol. Soc., 79, 1923, 423. 
revolutionary, and it might be advisable to await the result, before making generalizations of this sort.

I do not think that the Dunalastair belt of Grey Schist and Limestone, etc., to the north of the Tummel, is in the centre of a synform, nor that it is bounded to the east by a strip of Banded Group. My own field maps seem here to be widely different from those of the authors. The appearance of regularity which has been given to the outcrops of the different formations within this belt is, in my opinion, deceptive. Nor do I think that the authors have understood the structure of this part of Perthshire so thoroughly as to be able to claim that they have made " an important advance on Anderson's position".

E. M. Anderson.

\section{ZONAL POSITION OF THE ELSWORTH ROCK.}

Str,--I would like to ask Dr. Spath for the reference to any previous publication of the main thesis of my article (since he asserts it contains nothing much that is new): namely, that at Elsworth two distinct zones (cordatus and plicatilis) are represented, unmixed, in condensed ironshot facies, that the Elsworth Rock belongs to the plicatilis zone only, that the ironshot rock at Upware belongs only to the cordatus zone, and so is not the Elsworth Rock-equivalent, which at Upware is the Coralline Oolite. The passages I have quoted from the Cutch Memoir show that Dr. Spath regarded the ironshot rock at Upware as the Elsworth Rock, and the Elsworth Rock as containing a mixed or derived fauna.

Certainly the zonal position of the Elsworth Rock (at Elsworth) as given in Dr. Spath's memoir is unassailable, and it has not been assailed. In this particular his correlation agrees with that of his predecessors, Rigaux, Wedd, and myself.

Dr. Spath, without attempting to justify it, brings against me a serious charge of making "an entirely one-sided and misleading selection of passages and species and even dates of publication ", only to use them as skittles. In my article only two passages from his work are quoted. They are consecutive passages and are quoted en bloc, without expurgations. The quotations form a natural part of the introductory review of previous work, in order of dates of publication. They are the only passages that are relevant to the matter in hand. No species are "selected", for none are omittedunless Dr. Spath is suggesting that I ought to have reprinted his separate list of thirty-nine species from Elsworth and St. Ives. Believing 72 per cent of those items to stand in need of alteration, I considered it preferable only to refer to it and give my new list.

University Museum, W. J. ARKELL.

OXFORD.

8th December, 1937. 